DOI https://doi.org/10.30525/978-9934-588-46-4.02

\title{
ПРІОРИТЕТНІ НАПРЯМИ ТА ШЛЯХИ ЗАБЕЗПЕЧЕННЯ ІНФОРМАЦЙНОЇ ВІДКРИТОСТІ В ОРГАНАХ ПУБЛІЧНОЇ ВЛАДИ
}

\section{Грищенко І. М., Горбата Л. П.}

\section{ВСТУП}

Концепція «відкритого урядування» грунтується на тому, що ефективність громадських дій залежить від прозорості, підзвітності й колегіальності. «Відкритий уряд» забезпечує прийняття більш виважених рішень, сприяє зростанню рівня довіри громадськості до публічних інституцій, ефективності послуг і запобігає явищам корупції. Конгрес Ради Європи неодноразово закликав публічні органи влади через відкриті дані надавати громадянам доступ до інформації, що $\epsilon$ важливою передумовою їх впливу на роботу обраних ними представників влади. Ключовими елементами демократичного врядування зараз стали відкритість, прозорість, а також підзвітність.

У сучасному суспільстві можна виокремити такі пріоритетні напрями забезпечення інформаційної відкритості: доступ до публічної інформації; розвиток політики електронного урядування та відкритих даних.

Праця безпосередньо пов'язана 3 науковими дослідженнями кафедри публічного управління та менеджменту інноваційної діяльності Національного університету біоресурсів і природокористування України, які здійснюються в межах науково-дослідної теми «Теоретичні засади і механізми реалізації інноваційних процесів у публічному управлінні» (ДР № 118U100146).

Низка проблем інформаційного забезпечення органів публічної влади висвітлювалася в працях зарубіжних дослідників: Т. Вівшанта та Д. Кауфмана, К. Гуда, В. Карарго, Ф. Шоера, вітчизняних Е. Афоніна, А. Буханевича, Н. Гудими, О. Крета, Н. Крук, М. Лациби, Д. Ляпіна, В. Мельниченка, Р. Стадник та інших.

Хоча науковці зробили вагомий внесок у формування теоретикометодологічних основ з визначення функцій і шляхів забезпечення інформаційної відкритості органів влади, проте наукове розроблення не має системного характеру 3 урахуванням 
пріоритетних напрямів розвитку забезпечення інформаційної відкритості, недостатньо дослідженими залишилися окремі аспекти щодо шляхів відкритості в діяльності органів публічної влади. Це й зумовило вибір теми, постановку мети й завдань публікації.

Метою статті $є$ аналіз напрямів діяльності органів публічної влади, визначення їх пріоритетних шляхів забезпечення інформаційної відкритості.

Виходячи з мети, поставлено такі завдання:

- виокремити й узагальнити основні напрями діяльності органів публічної влади для забезпечення їх інформаційної відкритості;

- проаналізувати особливості кожного з пріоритетних напрямів;

- окреслити основні шляхи та визначити проблемні аспекти щодо забезпечення інформаційної відкритості органів публічної влади.

Отримані результати дають змогу сформулювати конкретні пропозиції та визначити шляхи вдосконалення діяльності органів публічної влади щодо забезпечення інформаційної відкритості.

\section{1. Забезпечення доступу до публічної інформації як один із пріоритетних напрямів інформаційної відкритості}

На сучасному етапі управлінська діяльність зазнає кардинальних змін. Корегується зміст, підвищується рівень інформаційнокомп'ютерних технологій i їх роль у збиранні та обробці управлінської інформації. Усе це зумовлює зростання важливості розвитку сфери інформаційного забезпечення процесу управління, яке полягає в збиранні й переробці інформації, необхідної для прийняття обгрунтованих управлінських рішень. Ведення управлінської діяльності викликає потребу у функціонуванні численних інформаційних потоків, що створюються в інформаційних процесах. Узагальнивши їх загалом, для аналізу можемо поділити на дві категорії:

- внутрішні, тобто інформаційні, відносини в межах органу публічної влади;

- зовнішні, що позначають інформаційні потоки та зв'язки, які встановлюються поза межами органу публічної влади для отримання необхідних для іiі функціонування відомостей.

Закон України «Про інформацію» визначає інформацію органів публічної влади одним із основних об'єктів інформаційних взаємовідносин у суспільстві та державі (ст. 21), а обов'язок цих органів інформувати про свою діяльність і прийняті рішення як гарантію права на інформацію (ст. 10). 
Оскільки право на доступ до інформації закріплено в Конституції України та відповідних законах, то наявні правові межі дають змогу громадянам скористатися таким правом та отримувати інформацію в повному обсязі.

Система концепцій, методів i засобів, що призначені для забезпечення користувачів інформацією, є складником інформаційного забезпечення органів публічної влади. Інформацію тут варто розглядати як певну сукупність різнопланових повідомлень, відомостей, даних про відповідні явища, процеси, відносини тощо. Ці дані відіграють в управлінні важливу роль, коли вони зібрані, перетворені на придатну для використання форму й систематизовані.

Основними якостями належного демократичного врядування визнаються відкритість i прозорість. Зокрема, 12 принципів належного врядування Ради Європи, закріплені в Європейській стратегії інновацій і належного врядування на місцевому рівні ${ }^{1}$, визначають вирішальними для належного демократичного врядування саме принципи «відкритого уряду».

Обов'язковим елементом відкритого урядування $є$ доступ до інформації, ще відомий як право на інформацію. Свобода доступу до інформації надає громадянам законні підстави вимагати від влади повну інформацію, яку належить оприлюднювати, якщо, звичайно, інформація не підпадає під вимоги спеціального винятку, визначеного законом. Чимало держав або територій мають положення про доступ до інформації в національних або федеральних законах чи чинних постановах 2 .

Право громадян на інформацію визнано міжнародними деклараціями, включно зі ст. 19 Загальної декларації прав людини, i міжнародними правозахисними трибуналами. Конвенція Ради Європи про доступ до офіційних документів визначає низку стандартів, які регулюють право на доступ до офіційних

CM Documents: official website of Council of Europe. URL: https://search.coe.int/cm/Pages/result_details.aspx?ObjectID=09000016805d47c5 (дата звернення: 09.03.2020).

2 Прозорість та відкритий уряд : матеріали Конгресу місцевих та регіональних влад Ради Європи. URL: https://rm.coe.int/booklet-a6-transparencycoll-public-ethic-ukr/168094eb8b (дата звернення: 09.03.2020). 
документів, включно 3 винятками, процедурами запиту, процедурами звинувачення та розгляду ${ }^{3}$.

Нормативно-правове забезпечення є важливою й необхідною умовою впровадження в життя відкритості органів публічної влади. У цьому плані прийнятий за основу у 2004 р. Закон України «Про інформаційну відкритість органів державної влади та вищих посадових осіб України» визначав умови й порядок забезпечення інформаційної відкритості в питаннях діяльності органів публічної влади 4 . Цей Закон поширювався на відносини, пов’язані 3 наданням органами публічної влади відомостей про себе та свою діяльність громадянам України та юридичним особам i регулював питання щодо обов'язкового оприлюднення інформації про органи публічної влади.

Отже, інформаційна відкритість органів публічної влади полягає у створенні для громадян i юридичних осіб України можливості вільно отримувати інформацію про ці органи та їх посадових осіб в обсягах і в порядку, установлених законодавством. Інформація, що оприлюднюється, має бути правдивою, повною й точною, реально відображати факти, що зазначені в запиті, станом на відповідну дату або за відповідний період часу.

Основною підставою для ефективності публічної влади, сформованої демократичним шляхом, $\epsilon$ відкритість. Коли відкритість відсутня, суспільний контроль за діями влади $\epsilon$ неможливим. Лише в тому випадку, якщо публічна влада «прозора», тобто відкрита, надає про свої рішення та дії повну й точну інформацію, правдива у своїх намірах, можна визначити, наскільки іiі дії відповідають закону та є моральними.

Уведення в науковий обіг і повсякденне життя терміна «транспарентність» зумовлено концепцією «відкритого суспільства», розробленою філософом К. Поппером. У праці «Відкрите суспільство та його вороги» автор розглядає «відкритість як багатоаспектне явище, що характеризується свободою поширення

${ }^{3}$ Рада Європи (2009 рік). Конвенція Ради Європи про доступ до офіційних документів; Серія договорів Ради Свропи № 205. URL: https://rm.coe.int/ 1680084826 (дата звернення: 09.03.2020).

${ }^{4}$ Про прийняття за основу Закону України про інформаційну відкритість органів державної влади та вищих посадових осіб України : Постанова Кабінету Міністрів України від 17 грудня 2004 року № 2265-IV / Верховна Рада України. URL: http://zakon1.rada.gov.ua/cgi-bin/laws/main.cgi (дата звернення: 09.03.2020). 
та отримання інформації від органів публічної влади за наявності розумних, установлених законом обмежень» 5 .

Безперечна необхідність відкритості публічної влади стає одним iз способів контролю 3 боку громадськості. Так, на думку О. Тофлера, «під час демократичного управління суспільством головною має стати «демасифікація» впливу кожного окремого громадянина на владу... I тут найближчі роки дадуть можливість побачити нові типи взаємодії, зокрема розвиток зв'язків 3 громадськістю також демонструє експлуатацію саме зворотного зв'язку від населення до влади, коли влада стає принципово залежною від інтересів населення» ${ }^{6}$.

Важливим $є$ саме комунікативний процес як варіант відкритості, через який відбувається надання громадянам державноуправлінських послуг і реалізація їх політичного волевиявлення.

Існують різні форми інформаційних стратегій, які становлять один iз факторів забезпечення відкритості, налагодження комунікації між владою та громадою, яка делегувала їй повноваження. Форми інформаційних стратегій можна вважати дзеркальним відбитком демократичності влади, адже під контролем громадськості влада повинна максимально розкрити зміст своєї діяльності, поступившись своєю конфіденційністю. Аргументом до сказаного вище може слугувати безперечне твердження, що демократія лише тоді зможе функціонувати досить ефективно, коли громадяни країни матимуть вичерпну інформацію 3 актуальних питань творення та реалізації публічної політики, що $є$ передумовою їх здатності брати участь у компетентному обговоренні дій влади та впливати на управлінські рішення.

Видається вартою на увагу думка I. Грищенко, що «керівники громад тоді $\epsilon$ ефективними менеджерами, коли їхня діяльність спрямована на постійне досягнення результатів у покращенні життєдіяльності громади, вони обрані на цю посаду знову й, урештірешт, покращили свою здатність спілкуватися та залучати громадськість до адміністрування, їхня потреба у владі стає більш соціально орієнтованою з певним часом» ${ }^{7}$.

5 Поппер К. Відкрите суспільство та його вороги: у полоні Платонових чарів / пер. $з$ англ. О. Коваленко. Київ : Основи, 1994. Т. 1. 444 с.

${ }^{6}$ Тоффлер О. Метаморфозы власти. Москва, 2003. 345 с.

7 Gryshchenko I. The impact on the formation of personal needs leadership. Scientific Bulletin of National Mining University (SciVerse Scopus). 2016. Vol. 4. P. 154-160. 
Однією 3 найважливіших форм налагодження взаємодії публічної влади та громадськості є публічна комунікація, яка має діяти у двох площинах, а саме: реагувати на запити громадськості, а завдяки цьому отримувати легітимність своїх рішень. «Відстеження громадської думки $є$ передумовою діяльності уряду, оскільки остання базується на інформації про настрої, сприйняття проблем і запитів громадян. Вплив на громадську думку належить до наслідків діяльності уряду, який вимагає прозорості й виправдання збоку громадськості. Урядова комунікація, попри притаманні їй окремі характеристики міжособистісної комунікації у вирішенні цих основних завдань, зорієнтована на широке коло громадськості, тобто масову аудиторію. Така природа урядової комунікації неминуче вимагає тісної співпраці 3 основними каналами спілкування з масовою аудиторією - засобами масової інформації» ${ }^{8}$.

Координуючим i регулювальним механізмом у взаєминах держави й суспільства є публічна комунікація, яка забезпечує стабільність та ефективність функціонування суспільства загалом. Публічній комунікації притаманна низка функцій, а саме:

- консервативна (спрямована на збереження статус-кво системи, що сприяє стабільному існуванню соціального організму);

- координувальна (покликана забезпечувати координацію впливів влади згідно з параметрами об’єкта управління);

- інтегрувальна (пов'язана зі здійсненням владної політики, яка б ураховувала інтереси всіх частин суспільства, сприяла виробленню й прийняттю узгоджених управлінських рішень);

- мобілізаційну (спрямовану на забезпечення легітимності чинного громадського порядку, одержання та схвалення суспільства з приводу прийнятих управлінських рішень);

- соціалізувальну (пов'язану із засвоєнням у процесі інформаційного обміну соціально-політичних норм, цінностей і традицій держави, підвищенням рівня політичної компетентності громадян) $)^{9}$.

Ці функції мають неоднакове значення на різних етапах реалізації публічної політики. На наш погляд, для держави загалом і публічної влади найважливішою є функція зниження соціальної напруженості, яка покликана забезпечити подальший поступ у сфері

${ }^{8}$ Тоффлер О. Метаморфозы власти. Москва, 2003. 345 с.

9 Bentele, Gunter. Politische Offentlichkeitsarbeit. Politikvermittlung und Demokratie in der Mediengesellschaft / Ulrich Sarcinelli (Hrsg.). Bonn, 1998. S. 124-145. 
демократичних зрушень. Відповідно до цього, дослідник політикокомунікативних процесів В. Шульц виділив такі канали публічної комунікації:

1) через неформальні канали;

2) через організації;

3) через засоби масової інформації ${ }^{10}$.

Характеризуючи пріоритетність каналів інформаційної взаємодії структур публічної влади та громадськості на сучасному етапі, варто відзначити, що основним каналом інформування в системі публічного управління стають засоби масової інформації. ЗМІ й інші медійні компанії нині $є$ потужним інструментом влади, за допомогою якого вона «цілеспрямовано конструює політичні порядки» ${ }^{11}$. Проте підвищення ролі медіа як каналу комунікації відбувається на тлі фактичної відсутності інформаційної взаємодії за допомогою інших каналів.

До інформування громадськості існують два загальні підходи. Відповідно до першого, влада сама визначає інформацію, яку варто розкрити для широкого загалу, і термін такого розкриття. Другий підхід має назву свободи інформації, коли громадськість має вільний доступ до будь-якої офіційної інформації, за винятком окремих випадків, коли влада висуває вагомі грунтовні причини (представляючи їх за необхідності на розгляд незалежних громадських інституцій), спрямовані на обмеження загального доступу.

Існують досить переконливі докази того, що відкритість влади реально сприяє поліпшенню ефективності інформаційної політики. Лише громадськість, яка добре поінформована про діяльність влади, може протистояти зловживанню владою, виявити іiі некомпетентність. Досягнути цього можна лише шляхом реалізації принципу свободи інформації. Упровадження перевірок та аналітичних заходів для спостереження й контролю за роботою органів публічної влади, заохочення громадян брати участь у прийнятті управлінських рішень - усе це результат дії принципу свободи інформації. Світова практика підтверджує це. У країнах, які ефективно впроваджують у життя принцип свободи інформації,

${ }^{10}$ Schulz, Wanfried. Neue Medien. Chancen und Risiken. Tendenzen der Medienentwicklung und ihre Folgen. Aus Politik und Zeitgeschichte. 1997. B. 42. S. 3-12.

${ }^{11}$ Schulz, Wanfried. Neue Medien. Chancen und Risiken. Tendenzen der Medienentwicklung und ihre Folgen. Aus Politik und Zeitgeschichte. 1997. B. 42. S. 3-12. 
вдається мінімізувати прийняття неефективних рішень публічної влади, підвищити рівень персональної відповідальності за них.

Визначено такі основні механізми інформування громадськості, до яких належать:

- широке інформування громади про мету, концепції та плани реалізації проєктів публічної влади; про залучення комунікативних ресурсів, необхідних для реалізації відповідного проєкту;

- підбір і навчання виконавців того чи іншого проєкту;

- контроль за реалізацією певного проєкту й інформування суспільства про успіхи і труднощі, 3 якими можна стикнутися в процесі його реалізації;

- аналіз результатів i подальше планування роботи 3 громадськістю.

Згідно із зазначеним вище, інформування громадськості можна розподілити на три етапи: підготовчий, основний і заключний ${ }^{12}$.

$\mathrm{He}$ можна не погодитися 3 думкою французького вченого Р. Лапревота, який уважає, що «інформування громадськості підвищує політичну культуру, у результаті цього держава стає зацікавленою в досягненні соціального консенсусу, а тому вона стає здатною творити гуманну політику, яка викликає в громадськості симпатію до влади» ${ }^{13}$.

Відповідно до цього, інформування громадськості має на меті:

- отримання консультацій від громадськості;

- виявлення можливих тенденцій наслідків політики;

- вивчення суспільної думки 3 метою визначення ії відповідності попереднім очікуванням;

- установлення й підтримка спілкування сторін, заснованого на правдивій і повній інформованості;

- запобігання конфліктам i напруженості між владою та громадою;

- сприяння формуванню взаємоповаги й соціальної відповідальності;

- гармонізацію особистих і суспільних інтересів ${ }^{14}$.

${ }^{12}$ Mertes, Michael. Bundeskanzleramt und Bundespresseamt. Das Informationsund Entscheidungsmanagement der Regierungszentrale. Information und Entscheidung. Kommunikationsmanagement der politischen Fuhrung. Wiesbaden, 2003. S. 52-79.

${ }_{13}$ Kiefer, Marie-Luise. Massenkommunaktion 1995, in: Media Perspektiven. 1996. S. 234-248.

14 Ackermann, Eduard. Mit feinem Gehor. Vierzig Jahre in der Bonner Politik. Bergisch Gladbach, 1994. 127 s. 
Для побудови громадянського суспільства важливе розуміння громадянами того факту, що вони живуть у своєму національно регламентованому суспільно-політичному просторі. Відповідна інформаційно-комунікативна стратегія покликана створювати такий погляд на відкритість влади. Інформація по телебаченню, радіо, в мережі Інтернет, повідомлення в газеті й соціальних мережах про звичайні події - найперші інструменти формування відкритості влади та доведення відомостей до громадськості на сучасному етапі. Зміст діяльності влади має бути функціонально-прозорим. Свого роду така відкритість має стати результатом фільтрації «масової свідомості довготривалої пульсації комунікативного простору держави» ${ }^{15}$.

Існує чимало свідчень, що ефективність роботи публічної влади 3 громадськістю значною мірою залежить від системи засобів масової інформації, яка включає не тільки пресу, радіо й телебачення. Ціла низка мультимедійних систем зв'язку впливає на процеси співпраці публічної влади і громади. Усе більшого значення набуває Інтернет, який забезпечує альтернативні можливості для передачі інформації, аналізу й мобілізації громадської участі у творенні публічної політики.

3'явилися нові форми демократичної практики відносин між громадськістю й публічною владою. Для багатьох органів публічної влади розповсюдження їхньої інформації безпосередньо серед населення, що звертається до їхніх веб-сайтів, створило умови мобілізації громадськості на підтримку здійснюваних ними кампаній, відкрило нові шляхи впливу на суспільну думку.

Найважливішою умовою існування демократії $є$ публічність політики, тобто відкритість будь-якої політичної дії. Громадяни мають право знати про дії та наміри органів публічної влади, вони можуть і повинні впливати на процеси створення й реалізації певних рішень, на якість роботи апарату публічної влади, бути поінформованими про рівень освіченості i громадянської самосвідомості представників публічної влади, які приймають рішення ${ }^{16}$.

Зокрема, публічна політика в сучасних умовах - це форма політичного процесу, який реалізується в публічному просторі,

15 Ackermann, Eduard. Mit feinem Gehor. Vierzig Jahre in der Bonner Politik. Bergisch Gladbach, 1994. 127 s.

${ }_{16}$ Шпортько О. Поле публічної політики. Політичний менеджмент. 2010. № 5 (44). С. 90-96. 
підтримується інформаційно-комунікаційними й іншими видами ресурсів, представлений цілісним комплексом вертикальних і горизонтальних взаємодій його учасників. Публічна політика стала специфічною формою комунікації суб'єктів політичного процесу, яка дає змогу активізувати участь громадян у формуванні, виробленні та реалізації політичного курсу. Варто зазначити, що публічна політика - це особливий вид комунікації, який не $\epsilon$ сферою боротьби за завоювання влади ${ }^{17}$.

Отже, якість нормативно-правової бази та вільний доступ громадян до інформації про діяльність органів публічної влади є головними чинниками її відкритості.

\section{2. Роль електронного урядування й розвиток політики відкритих даних у забезпеченні інформаційної відкритості}

Кількість інформаційних потоків, що циркулюють у суспільстві, неухильно й суттєво зростає протягом останнього часу. Усе більша кількість громадян залучена до використання електронних пристроїв, що слугують не тільки для зв'язку, інформування, а й передачі інформації, у тому числі офіційно-ділової.

Уряд України схвалив Концепцію розвитку електронного урядування в країні. Концепцією визначено напрями, механізми й терміни формування ефективної системи електронного урядування в Україні для задоволення інтересів і потреб фізичних і юридичних осіб, удосконалення системи публічного управління, підвищення конкурентоспроможності та стимулювання соціальноекономічного розвитку держави.

Реалізація Концепції розвитку електронного урядування на місцевому рівні дасть можливість:

- підвищити ефективність роботи органів місцевого самоврядування й досягти якісно нового рівня управління, що базується на принципах результативності, ефективності, прозорості, відкритості, доступності, довіри та підзвітності;

- покращити якість надання публічних послуг фізичним і юридичним особам відповідно до європейських вимог, а також забезпечити необхідну мобільність і конкурентоспроможність громадян і суб'єктів господарювання в сучасних економічних умовах;

17 Публічна політика та управління : наукова розробка / авт. кол. : С. Телешун, О. Титаренко, С. Ситник, С. Вировий. Київ : НАДУ, 2010. 36 с. 
- мінімізувати корупційні ризики під час виконання владних повноважень; покращити інвестиційну привабливість, діловий клімат і конкурентоспроможність країни; стимулювати соціальноекономічний розвиток в Україні.

Електронне урядування має певні стратегічні завдання:

- забезпечення прав громадян на доступ до всіх видів відкритої державної інформації, що має індивідуальну та суспільну значимість;

- залучення громадян до участі в державних справах;

- удосконалення технології публічного управління;

- подолання інформаційної нерівності;

- організація надання послуг юридичним і фізичним особам в інтегрованому вигляді дистанційно - через Інтернет - та інші засоби;

- перебудова відносин із громадянами;

- надання громадянам можливості навчатися протягом усього життя;

- сприяння розвитку економіки;

- системоутворювальне законодавче забезпечення.

Як видно із зазначених вище стратегічних завдань, метою впровадження електронного урядування в Україні $\epsilon$ досягнення європейських стандартів якості електронних адміністративних послуг, відкритості й прозорості влади для громадян, представників бізнесу та громадських організацій.

Електронне урядування виконує такі основні функції:

- підвищення якості й доступності послуг для громадян, спрощення процедур і скорочення адміністративних витрат;

- підвищення якості адміністративних та управлінських процесів, забезпечення контролю за результативністю діяльності органів виконавчої влади з одночасним забезпеченням належного рівня інформаційної безпеки;

- забезпечення відкритості інформації про діяльність органів виконавчої влади, розширення доступу до неї та надання можливості безпосередньої участі громадян та інститутів громадянського суспільства в процесах підготовки й експертизи проектів рішень, які приймаються на всіх рівнях державного управління;

- видача дозволів (на займання окремими видами підприємницької діяльності; на проведення мітингів, демонстрацій; на розміщення реклами тощо), у тому числі акредитація, атестація, сертифікація; 
- реєстрація (прав власності, актів громадянського стану, суб'єктів підприємницької діяльності, об'єднань громадян тощо);

- легалізація документів (консульська легалізація), нострифікація (визнання дипломів, виданих в інших країнах) і верифікація (установлення достовірності сертифікатів про походження товарів);

- визнання певного статусу, прав особи (призначення пенсій, субсидій $)^{18}$.

Від упровадження електронного урядування насамперед виграють ті споживачі послуг, які претендують на послуги видачі дозволів i реєстрації; «змішаного» рівня регулювання адміністративних повноважень i ті, що потребують комплексної за змістом послуги. За умови електронного урядування користувач має можливість звертатися до одного державного «базового» органу влади для отримання послуги від усіх «пов'язаних» із «базовим» органів влади. Це стає можливим за умови об'єднання за допомогою інтернет-технологій усіх органів публічної влади в єдиний комплекс із вищим ступенем інтегрування внутрішніх процесів (документообіг) і єдиним інтерфейсом (вікном взаємодії) із громадянином (користувачем). Отже, громадянин одержить можливість спілкуватися з єдиним електронним посередником, що репрезентує всі одночасно відомства, а не з кількома по черзі, що суттєво економить i час, i людський ресурс. Також запит чи звернення громадянина автоматично надсилається у відповідні інстанції, у більшості випадків відповідь (юридична консультація, квитанція про оплату послуг, бюлетень для голосування, довідка, податкова декларація) приходить негайно.

Варто відзначити значний економічний ефект від створення «електронного урядування». Електронна взаємодія громадян з органами влади удвічі менш витратна, ніж та, що здійснюється за допомогою реального офісу. Про це свідчить досвід країн, яким вдалося впровадити електронне урядування.

В умовах сьогодення електронні комунікації, інформаційне суспільство та аудіовізуальний ринок зазнають динамічних і суттєвих змін. Тому прорахунки, суперечності в цій сфері більш помітні, а законодавчі зміни є нагальною необхідністю.

Можна визначити низку напрямів i шляхів забезпечення інформаційної відкритості в органах публічної влади, без

18 Електронний уряд : науково-практичний довідник / укладачі: С. Чукут, I. Клименко, К. Линьов. Київ, 2016. 85 с. 
упровадження яких неможливий поступ вперед у політиці відкритості влади.

Перший напрям - інтероперабельність (Interoperability) та електронні сервіси (eServices) - передбачає долучення України до Програми СC Interoperability Solutions for European Public Administrations 2, проєктів е-CODEX, e-Invoicing, а також ініціативи Single Digital Gateway.

Схвалення Концепції розвитку електронного урядування в Україні відбулося ще 20 вересня 2017 р. Розпорядженням Кабінету Міністрів України № 649-р. Концепція спрямована на підтримку координації та співпраці органів публічної влади для досягнення необхідного рівня ефективності й результативності розвитку електронного урядування, просування ідеї реформування публічного управління та децентралізації на базі широкого використання сучасних інформаційно-комунікаційних технологій по всій країні.

Доступ до того чи іншого державного реєстру або бази даних потреба кожного суб'єкта господарювання як державної, так i приватної форм власності. Такий доступ може забезпечити єдине митне вікно, система електронних декларацій, система електронних закупівель тощо, для повноцінного функціонування яких необхідна інтеграція із зовнішніми державними реєстрами та базами даних.

Швидкість і якість прийняття рішень значною мірою впливає на ефективність функціонування сучасної публічної влади. Виникає нагальна потреба в наявності електронного документообігу. Локальний електронний документообіг (на рівні одного відомства) дає змогу структурі влади автоматизувати всі процеси роботи 3 документами, максимально відмовитися від паперу, пришвидшити процес прийняття управлінських рішень і вдосконалити внутрішню дисципліну.

Закон України «Про адміністративні послуги» від 06.09.2012 № 5203-VI забороняє вимагати від суб'єктів звернення інформацію або дані, що перебувають в інших органах влади, тобто вже були надані громадянами раніше. Однак спростити порядок надання послуг i виконати вимоги Закону неможливо через відсутність електронної взаємодії державних систем. Постанова Кабінету Міністрів України «Деякі питання електронної взаємодії державних електронних інформаційних ресурсів» від 08.09.2016 № 606 передбачає запровадження системи електронної взаємодії державних електронних інформаційних ресурсів під час надання адміністративних послуг i здійснення інших повноважень 
відповідно до покладених на них завдань і підключення до електронної взаємодії відповідно до вимог $\mathrm{CC}^{19}$.

Другий напрям - відкриті дані, розвиток яких в Україні забезпечить підвищення відкритості, прозорості й ефективності роботи органів публічної влади, є шляхом до розвитку нової для нашої держави цифрової індустрії - індустрії відкритих даних. Інтеграція Єдиного державного веб-порталу відкритих даних України - data.gov.ua - до Центрального європейського порталу відкритих даних - europeandataportal.eu та data.europa.eu, $є$ головним завданням цього напряму ${ }^{20}$.

Існує Центральний європейський портал відкритих даних, який запроваджує єдині вимоги до політики розвитку відкритих даних i до їх стандартів. Він $є$ точкою доступу до відкритих даних установ та організацій Європейської Комісії, а також держав-членів СС. У нашій країні державним органом, що відповідає за реалізацію політики відкритих даних, $є$ Міністерство цифрової трансформації України (Державне агентство 3 питань електронного врядування України).

Порівняно недавно виникло як доповнення до відкритого уряду поняття «відкриті дані». Для їх реалізації необхідне вдосконалення інформаційно-комп'ютерних технологій, щоб полегшити й прискорити збирання, опублікування та опрацьовування великої кількості даних. Відповідно до «Відкритого визначення», «відкриті дані й матеріали можуть бути вільно використані, модифіковані та доступні для будь-яких цілей» ${ }^{21}$. Щоб дані можна було вважати відкритими, важливими є три якості: вільне використання, повторне використання й публікація.

Міжнародна хартія відкритих даних, ініційована 2015 р., визначає шість принципів випуску даних:

1. Одразу відкритий.

2. Своєчасний і всеосяжний.

19 Деякі питання електронної взаємодії державних електронних інформаційних ресурсів : Постанова Кабінету Міністрів України від 8 вересня 2016 року № 606 / Верховна Рада України. URL: https://zakon.rada.gov.ua/ laws/show/606-2016-\%D0\%BF (дата звернення: 09.03.2020).

20 Духовна О. Україна «в цифрі»: напрямки реформування. Офічіийиий сайт юридичної газети Onlin. № 45-46 (699-700). URL: https://yurgazeta.com/publications/practice/informaciyne-pravo-telekomunikaciyi/ukrayina-vcifri-napryamki-reformuvannya.html (дата звернення: 09.03.2020).

21 The Open Definition. URL: http://opendefinition.org/ (дата звернення: 09.03.2020). 
3. Доступний і застосовний.

4. Зіставний і сумісний.

5. Для покращення управління та залучення громадян.

6. Для всебічного розвитку й інновацій ${ }^{22}$.

Станом на початок 2020 р., до Міжнародної хартії відкритих даних приєдналися 9 українських міст: Вінниця, Дніпро, Дрогобич, ІваноФранківськ, Кропивницький, Львів, Тернопіль, Хмельницький, Чернівці. Вони запровадили портали відкритих даних своїх міст та активно їх наповнюють.

Доступність, усеосяжність і надійність інформації забезпечують належне діловодство, гарантуючи доступ до інформації та відкритість даних. Однак, як зазначено в Керівництві з відкритого уряду, «саме діловодство не досягне відкритості, але відкритість неможлива без нього» ${ }^{23}$.

Належні процедури діловодства дають низку гарантій, зокрема на достовірність і надійність інформації, на іiі легке і швидке отримання, збереження протягом визначеного часу. Також належне діловодство дає можливість безпечного та правильного розпорядження інформацією, гарантує надійний захист, якщо вона приватна або конфіденційна.

Третім напрямом забезпечення інформаційної відкритості в органах публічної влади є електронна ідентифікація (eID). У 2014 p. в $\mathrm{CC}$ ухвалений Регламент № 910 (elDAS), метою якого $\epsilon$ запровадження єдиних вимог до розвитку електронної ідентифікації, надання електронних довірчих послуг у країнах $\mathrm{CC}$ i розвиток трансграничної е-ідентифікації. Проєкт фокусується на виробленні стандартів, форматів, ідентифікаторів для засобів електронної ідентифікації у сферах е-медицини, електронних публічних послугах, е-банкінгу та повинен сприяти розвитку EU Digital Single Market, запровадженню транскордонної взаємодіï, підвищенню мобільності громадян і бізнесу $\mathrm{CC}^{24}$.

22 Прозорість та відкритий уряд : матеріали Конгресу місцевих та регіональних влад Ради Свропи. URL: https://rm.coe.int/booklet-a6-transparencycoll-public-ethic-ukr/168094eb8b (дата звернення: 09.03.2020).

23 Керівництво 3 Відкритого уряду (без дати). Діловодство. URL: http://www.opengovguide.com/topics/records-management/ (дата звернення: 09.03.2020).

24 Керівництво з Відкритого уряду (без дати). Діловодство. URL: http://www.opengovguide.com/topics/records-management/ (дата звернення: 09.03.2020). 
Міністерство цифрової трансформації України на початку 2020 р. провело презентацію мобільного додатку «Дія» та національної онлайн-платформи «Дія. Цифрова грамотність». Це мобільний застосунок, покликаний зберігати всі необхідні документи в електронному вигляді. Запущено в тестовому режимі електронні посвідчення водія та свідоцтво про реєстрацію транспортного засобу.

Перша національна онлайн-платформа «Дія. Цифрова грамотність» покликана сприяти громадянам в освоєнні базових цифрових навичок, батькам - убезпечити перебування дітей в Інтернеті, а вчителям пропонує онлайн-інструменти для проведення уроків.

Реалізація проєкту дасть можливість створити електронні публічні сервіси, що зменшать взаємодію 3 посадовцями. Також буде поліпшено доступ українців до Інтернету. Передбачається робота над підвищенням рівня цифрової грамотності. Передбачається, що кількість чиновників, що приймають рішення, буде зведено до мінімуму. Створюється єдиний портал, де буде зібрано всі державні послуги. Інформація 3 усіх реєстрів для кожного громадянина зосередиться в єдиному акаунті. Людина отримає можливість доступу до всіх даних, якими володіє про неї держава. Важливо, що користувач буде отримувати повідомлення про спробу отримати доступ до його персональних даних. Пропонується, окрім Міністерства цифрової трансформації, створити відповідні посади в кожному органі публічної влади.

Нагальними для прийняття щодо всіх напрямів залишається Закон України «Про захист персональних даних» у новій редакції, який відображатиме реформу, що відбулася в $\mathrm{CC}$, а також закони про об'єкти критичної інфраструктури й електронні комунікації, які внесені до переліку пріоритетних для першочергового розгляду та ухвалення.

Для втілення в життя запланованої «цифровізації» й переходу на більш високий технологічний рівень розвитку в нашій країні $\epsilon$ всі необхідні умови. Основними характеристиками економічного розвитку повинні стати величина i швидкість цифрових трансформацій, які супроводжуються формуванням належної правової бази, цифрові технології стимулюватимуть розвиток відкритого інформаційного суспільства як одного 3 важливих 
чинників розвитку демократії в країні, підвищення продуктивності, економічного зростання та якості життя громадян України ${ }^{25}$.

\section{ВИСНОВКИ}

У діалозі публічної влади та громади необхідною є обов'язкова звітність органів влади про іiі діяльність незалежно від наявності запитів і звернень громадян, а також інформування громади про поточну діяльність влади. Подальше коригування законодавства України, що йтиме в цьому напрямі, є пріоритетним на сучасному етапі.

Сьогодні державою сформовано цілу низку механізмів залучення громадян до прийняття рішень. Головними причинами того, що більшість із механізмів не працюють належним чином, $\epsilon$ прорахунки в роботі представників влади, які не вміють або не хочуть застосовувати принципи прозорості й відкритості та переходити до процедур публічної політики. Важливим кроком уникнення цього $є$ визнання організацій громадянського суспільства рівними партнерами і проведення консультації $з$ ними.

Для покращення ситуації щодо прозорості й відкритості органів публічної влади доцільно розробити комплексну програму діяльності, передбачивши в ній реалізацію конкретних і дієвих заходів за такими напрямами:

1. Удосконалення нормативно-правового забезпечення. Передбачити реалізацію таких дій: уточнення положень законодавства про діяльність органів влади в реалізації публічної політики в частині визначення інформування громадян про поточну діяльність органу влади; створити централізовані реєстри чинних законів та інших нормативно-правових актів; переглянути механізм залучення громадян до процесів прийняття управлінських рішень.

2. Формування суспільного попиту на інформацію про діяльність органів публічної влади, інтересу громадян щодо іiї отримання шляхом створення інформаційних сервісів з поширення електронної оперативної інформації про послуги органів публічної влади та вакантні місця в них, про роботу органів публічної влади й алгоритми участі в суспільно важливих процесах; створення інформаційного центру органів публічної влади або розширення

25 Духовна О. Україна «в цифрі»: напрямки реформування. Офіційиий сайт юридичної газети Onlin. № 45-46 (699-700). URL: https://yurgazeta.com/publications/practice/informaciyne-pravo-telekomunikaciyi/ukrayina-vcifri-napryamki-reformuvannya.html (дата звернення: 09.03.2020). 
повноважень «прозорих офісів», наявність яких зробила б доступнішою інформацію про діяльність влади, послуги й компетенцію органів публічної влади та їх працівників.

3. Надання онлайн послуг органами публічної влади, щоб громадяни могли отримувати інформацію, надсилати запити, брати участь у голосуванні, подавати заяви та взаємодіяти з посадовими особами з використанням цифрових технологій.

4. Створення ефективних механізмів контролю для забезпечення прозорості й відкритості органів публічної влади в реалізації публічної політики через систему засобів масової інформації.

5. Удосконалення інструментів, основних процедур і врахування результатів онлайн консультацій у процесі прийняття управлінських рішень.

Саме відкритість органів публічної влади, іiї здатність, спроможність i готовність до діалогу 3 різними інститутами громадянського суспільства в основному впливає на процеси консолідації влади та громади. Проаналізувавши результати наукових досліджень, можемо підбити підсумки, що забезпечення принципу відкритості органів публічної влади $\epsilon$ запорукою демократизації суспільства загалом.

\section{АНОТАЦІЯ}

У статті охарактеризовано основні напрями забезпечення інформаційної відкритості в діяльності органів публічної влади. 3'ясовано сутність поняття відкритості діяльності органів публічної влади: перебування під контролем громадськості, відкритість i доступність інформації для громадян, розвиток політик відкритих даних та е-урядування. Окреслено пріоритетні шляхи забезпечення інформаційної відкритості. Визначено проблемні питання подальших наукових пошуків і коригування нормативно-правових актів, що регулюють інформаційну відкритість у діяльності органів публічної влади. Розкрито питання прозорості, підзвітності, колегіальності. Досліджено принцип відкритості й прозорості 3 плеяди принципів Good Governance. Охарактеризовано поняття транспарентності та його значення в діяльності органів публічної влади. Виокремлено й окреслено форми інформаційних стратегій, систематизовано й охарактеризовано функції публічної комунікації.

\section{ЛІТЕРАТУРА}

1. Деякі питання електронної взаємодії державних електронних інформаційних ресурсів : Постанова Кабінету Міністрів України від 
8 вересня 2016 року № 606 / Верховна Рада України. URL: https://zakon.rada.gov.ua/laws/show/606-2016-\%D0\%BF (дата звернення: 09.03.2020).

2. Духовна О. Україна «в цифрі»: напрямки реформування. Офіиійний сайт юридичної газети Onlin. № 45-46 (699-700). URL: https://yur-gazeta.com/publications/practice/informaciyne-pravotelekomunikaciyi/ukrayina-v-cifri-napryamki-reformuvannya.html_(дата звернення: 09.03.2020).

3. Електронний уряд : науково-практичний довідник / укладачі : С. Чукут, І. Клименко, К. Линьов. Київ, 2016. 85 с.

4. Керівництво з Відкритого уряду (без дати). Діловодство. URL: http://www.opengovguide.com/topics/records-management/ (дата звернення: 09.03.2020).

5. Поппер К. Відкрите суспільство та його вороги: у полоні Платонових чарів / пер. $з$ англ. О. Коваленко. Київ : Основи, 1994. T. $1.444 \mathrm{c}$.

6. Про прийняття за основу Закону України про інформаційну відкритість органів державної влади та вищих посадових осіб України : Постанова Кабінету Міністрів України від 17 грудня 2004 року № 2265-IV / Верховна Рада України. URL: http://zakon1.rada.gov.ua/ cgi-bin/laws/main.cgi (дата звернення: 09.03.2020).

7. Прозорість та відкритий уряд : матеріали Конгресу місцевих та регіональних влад Ради Європи. URL: https://rm.coe.int/bookleta6-transparency-coll-public-ethic-ukr/168094eb8b (дата звернення: 09.03.2020).

8. Публічна політика та управління : наукова розробка / авт. кол. : С. Телешун, О. Титаренко, С. Ситник, С. Вировий. Київ : НАДУ, 2010. 36 с.

9. Рада Свропи (2009 рік). Конвенція Ради Європи про доступ до офіційних документів; Серія договорів Ради Свропи № 205. URL: https://rm.coe.int/1680084826 (дата звернення: 09.03.2020).

10. Тоффлер О. Метаморфозы власти. Москва, 2003. 345 с.

11. Шпортько О. Поле публічної політики. Політ. менеджмент. 2010. № 5 (44). C. 90-96.

12. Ackermann, Eduard. Mit feinem Gehor. Vierzig Jahre in der Bonner Politik. Bergisch Gladbach, 1994. 127 s.

13. Bentele, Gunter. Politische Offentlichkeitsarbeit, in: Politikvermittlung und Demokratie in der Mediengesellschaft. Ulrich Sarcinelli (Hrsg.). Bonn, 1998. S. 124-145. 
14. CM Documents: official website of Council of Europe. URL: https://search.coe.int/cm/Pages/result_details.aspx?ObjectID=090000168 05d47c5 (дата звернення: 09.03.2020).

15. Endorsed by - International Open Data Charter. International Open Data Charter (en-US). URL: https://opendatacharter.net/ (дата звернення: 09.03.2020).

16. Gryshchenko I. The impact on the formation of personal needs leadership. Scientific Bulletin of National Mining University (SciVerse Scopus). 2016. Vol. 4. P. 154-160.

17. Kiefer, Marie-Luise. Massenkommunaktion 1995. Media Perspektiven. 1996. S. 234-248.

18. Mertes, Michael. Bundeskanzleramt und Bundespresseamt. Das Informations-und Entscheidungsmanagement der Regierungszentrale. Information und Entscheidung. Kommunikationsmanagement der politischen Fuhrung. Wiesbaden, 2003. S. 52-79.

19. Schulz, Wanfried. Neue Medien. Chancen und Risiken. Tendenzen der Medie-nentwicklung und ihre Folgen. Aus Politik und Zeitgeschichte. 1997. B. 42. S. 3-12.

20. The Open Definition. URL: http://opendefinition.org/_(дата звернення: 09.03.2020).

\section{Information about authors:} Gryshchenko I. N.,

Doctor of Science in Public Administration, Professor of the Department of Public Administration and Innovation Management of the Education and Research Institute of Continuing Education of the National University of Life and Environmental Sciences of Ukraine 11, Heroiv Oborony Str., Kyiv, 03041, Ukraine

Gorbata L. P., Postgraduate Student of the Department of Public Administration and Innovation Management of the Education and Research Institute of Continuing Education of the National University of Life and Environmental Sciences of Ukraine 11, Heroiv Oborony Str., Kyiv, 03041, Ukraine 